\title{
Human Hepatic Lipocytes Synthesize Tissue Inhibitor of Metalloproteinases-1 Implications for Regulation of Matrix Degradation in Liver
}

\author{
John P. Iredale, Gillian Murphy, ${ }^{\star}$ Rosalind M. Hembry, ${ }^{*}$ Scott L. Friedman, ${ }^{\star}$ and Michael J. P. Arthur \\ Department of Medicine II, University of Southampton, United Kingdom; *Strangeways Laboratory, Cambridge, United Kingdom; \\ and ${ }^{\ddagger}$ Liver Center Laboratory, San Francisco, California 94110
}

\begin{abstract}
Hepatic lipocytes play a central role in the pathogenesis of liver fibrosis, both via production of extracellular matrix proteins and through secretion of matrix metalloproteinases. In this study, we have characterized lipocyte expression and release of tissue inhibitor of metalloproteinases-1 (TIMP-1), an important inhibitor of metalloproteinase activity, whose role in liver has not previously been examined.

TIMP-1 was immunolocalized to human lipocytes, and secretion of TIMP-1 was confirmed by ELISA of culture media; (mean \pm SD) $159 \pm 79 \mathrm{ng}$ of TIMP-1/10 cells per $24 \mathrm{~h}$. Evidence for functional inhibitory activity of released TIMP-1 was obtained by $(a)$ reverse zymography that demonstrated a single inhibitor band, $M_{\mathrm{r}} 28 \mathrm{kD}$, that co-migrated with a TIMP-1-positive control sample; and (b) unmasking of inhibited gelatinase activity in lipocyte medium by separating it from TIMP-1 using gelatin sepharose chromatography; gelatinase activity in chromatographed medium increased more than 20-fold, compared with unfractionated medium, and could be reinhibited by adding back fractions that contained inhibitor. By Northern analysis, freshly isolated human lipocytes exhibited low levels of mRNA expression for TIMP-1, but this increased markedly relative to $\beta$-actin expression with lipocyte activation during cell culture.

We conclude that human hepatic lipocytes synthesize TIMP-1, a potent metalloproteinase inhibitor, and that TIMP1 expression increases with lipocyte activation. These data indicate that hepatic lipocytes can regulate matrix degradation in the liver, and suggest that expression of TIMP-1 by activated lipocytes may contribute to the progression of liver fibrosis. $(J$. Clin. Invest. 1992. 90:282-287.) Key words: metalloproteinase - liver fibrosis
\end{abstract}

\section{Introduction}

In normal liver, hepatic lipocytes (fat-storing or Ito cells) are located in the space of Disse. They comprise approximately

Address correspondence to Dr. M. J. P. Arthur, Medicine II, LD 68, South Lab and Path Block, Southampton General Hospital, Tremona Road, Southampton, Hampshire S09 4XY, UK.

Received for publication 16 December 1991 and in revised form 19 February 1992.

J. Clin. Invest.

(C) The American Society for Clinical Investigation, Inc.

0021-9738/92/07/0282/06 \$2.00

Volume 90, July 1992, 282-287 one third of nonparenchymal cells and are distributed throughout the liver (1).

Accumulating evidence has established a prominent role for lipocytes in hepatic fibrogenesis. In liver injury of humans and experimental animals, lipocytes transform to a myofibroblast-like phenotype, proliferate, and are most abundant in regions of active fibrosis $(2,3)$. By in situ hybridization, mRNA's for interstitial collagens are localized predominantly to activated lipocytes both in animal models of liver fibrosis $(4,5)$ and human liver disease (6). In culture, rat and human lipocytes synthesize interstitial collagens $(7,8)$, laminin $(9)$, fibronectin (10), and proteoglycans (11).

Recent evidence demonstrates that under certain conditions hepatic lipocytes also synthesize matrix metalloproteinases and may contribute to matrix degradation in liver. We have shown that cultured rat and human lipocytes synthesize and release $72 \mathrm{kD}$ type IV collagenase/gelatinase $(12,13)$. Myofibroblast-like cells derived from human liver explants of presumed lipocyte origin have been reported to release interstitial collagenase activity when exposed to IL-1 or tumor necrosis factor- $\alpha$ (14). Hepatic lipocytes have also been shown by in situ hybridization to express mRNA for transin after carbon tetrachloride liver injury (15). Other nonparenchymal cells can also synthesize metalloproteinases; for example, interstitial collagenase (16) and $92 \mathrm{kD}$ type IV collagenase/gelatinase, by Kupffer cells (17).

Mechanisms for the control and regulation of matrix degradation in liver have not been documented. In general, metalloproteinases are regulated by three mechanisms (18): regulation of metalloproteinase gene expression, activation of proenzymes, and inhibition of active forms by the specific tissue inhibitors of metalloproteinases, (TIMP-1) ${ }^{1}$ and TIMP-2. In view of their central role in both matrix synthesis and degradation, we have examined whether hepatic lipocytes synthesize and release metalloproteinase inhibitors. Our studies have concentrated primarily on the synthesis and inhibitory activity of released TIMP-1.

Our data demonstrate that activated human lipocytes express the gene for TIMP-1, synthesize and release immunoreactive TIMP-1, and that the released TIMP-1 exhibits inhibitory activity against metalloproteinases. The significance of our findings to regulation of matrix degradation in liver is discussed.

1. Abbreviation used in this paper: TIMP-1, tissue inhibitors of metalloproteinases-1. 


\section{Methods}

Human hepatic lipocyte isolation and culture. Hepatic lipocytes were obtained from normal human liver tissue by pronase/collagenase perfusion and purified by arabinogalactan density gradient centrifugation, as previously described (8). Lipocytes were harvested from the $<6 \%$ or $6-8 \%$ arabinogalactan interface and identified by phase contrast microscopy (Fig. $1 \mathrm{~A}$ ) and endogenous vitamin A autofluorescence (8). Cell purity consistently exceeded $90 \%$, with Kupffer cells as the main contaminant.

Cells were cultured on uncoated plastic 35-mm dishes (Lux; Miles Scientific Div., Miles Laboratories, Naperville, IL) in medium 199, supplemented with $10 \%$ fetal calf and $10 \%$ horse serum (Flow Labs., Inc., Irvine, CA). Media were changed every $24 \mathrm{~h}$.

Immunostaining for TIMP-1. To optimize intracellular protein accumulation, cultured lipocytes (day 14) were incubated in medium 199 containing $5 \mu \mathrm{mol}$ monensin (Sigma Chemical Co., Poole, UK) for $4 \mathrm{~h}$. Cells were fixed and immunostained as previously described (19), using a polyclonal sheep anti-human TIMP IgG $(50 \mu \mathrm{g} / \mathrm{ml})$ or nonimmune sheep IgG $(50 \mu \mathrm{g} / \mathrm{ml}$; Sigma Chemical Co. $)$ in controls and FITC-conjugated donkey anti-sheep secondary antibody (Sigma Chemical Co.) diluted 1:100 in PBS, pH 7.4. Dual immunostaining was performed with either murine anti-human desmin antibodies (1:50 dilution; Dako Ltd., High Wycombe, UK) or MAC-387 1:12,000 dilution (a monoclonal antibody that stains Kupffer cells and other macrophages [20], kindly provided by Dr. D. Flavell, Southampton General Hospital), using RITC-conjugated rabbit anti-mouse secondary antibody (Dako Ltd.) at dilutions of 1:25-1:100.

Media collection for analysis of proteinase and inhibitor release. Cell cultures maintained in serum-containing media for 7-14 d were washed threefold in serum-free medium 199 and preincubated for $4 \mathrm{~h}$ in the same medium, which was then discarded. The cells were then incubated in fresh medium 199 without serum, which was harvested after $24 \mathrm{~h}$. The media were clarified by centrifugation and stored at $-20^{\circ} \mathrm{C}$ before lyophilization. Blank medium not added to cells was included as a negative control. Samples were transported to the UK
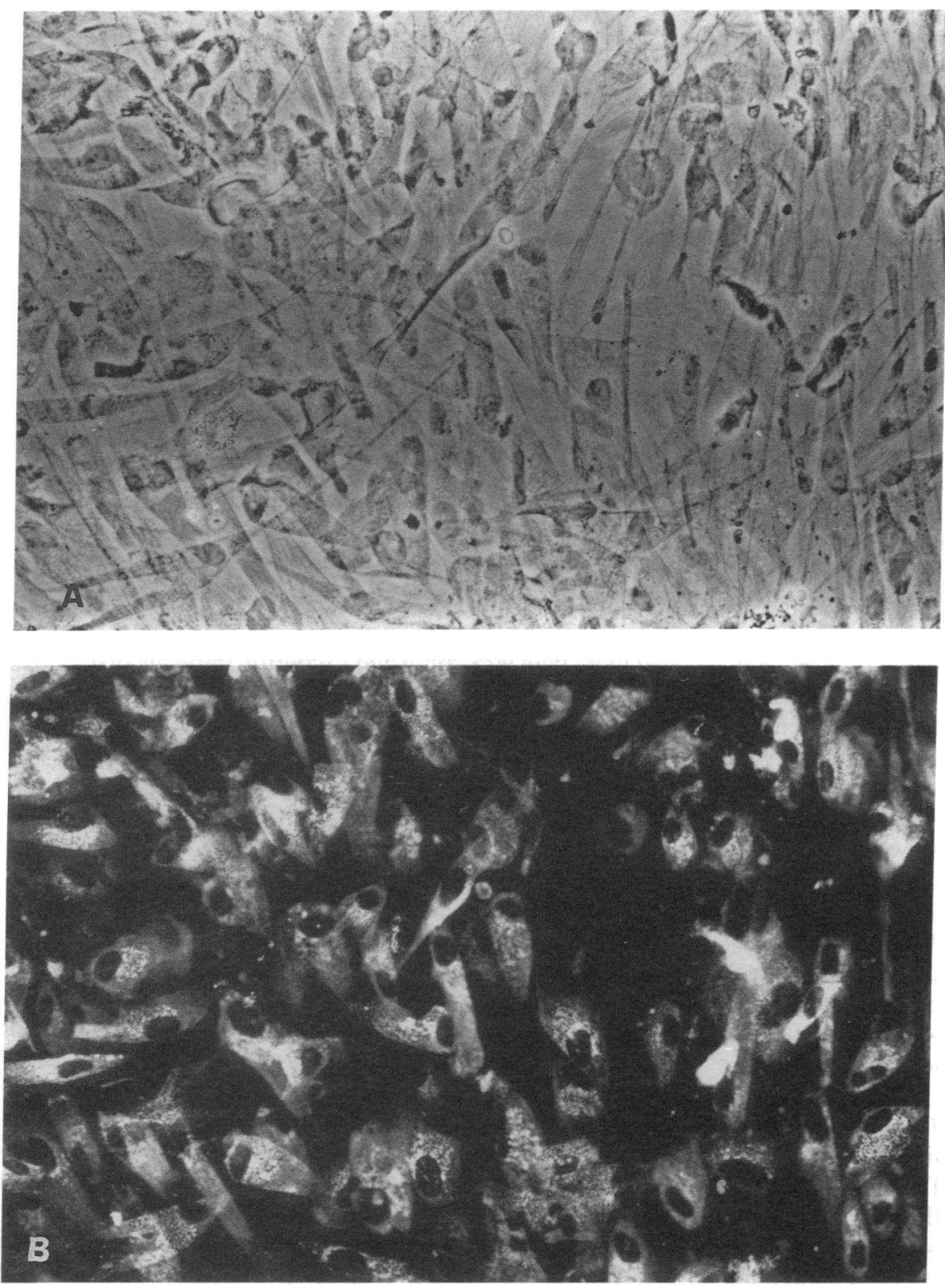

Figure 1. Phase contrast micrograph $(A)$ of human lipocytes at day 14 in primary culture. The cells were cultured in monensin 5 $\mu \mathrm{mol}$ for $4 \mathrm{~h}$ and then immunostained as described in Methods for TIMP-1. Positive fluorescence for TIMP-1 is demonstrated in the same field in $B$. 
lyophilized, reconstituted to original volume on arrival, and stored at $-20^{\circ} \mathrm{C}$ before analysis of TIMP content, proteinase, and proteinase inhibitor activity, as described below.

ELISA for TIMP-1. Immunoreactive TIMP-1 in crude human lipocyte medium was determined by ELISA as previously described (21).

Reverse zymography. $10 \mu \mathrm{l}$ of crude human lipocyte media were subjected to reverse zymography as described by Ward et al. (22).

Gelatin sepharose chromatography. Gelatinase activity in human lipocyte media was separated from metalloproteinase inhibitors by gelatin sepharose chromatography, according to the method of Overall et al. (23), with modification. In brief, $1 \mathrm{ml}$ of gelatin sepharose (Pharmacia-LKB Biotechnology, Milton Keynes, UK) was packed into a 1-ml tuberculin syringe and equilibrated with chromatography buffer $(0.05$ M Tris, $\mathrm{pH} 7.6,0.2 \mathrm{M} \mathrm{NaCl}, 0.02 \% \mathrm{NaN}_{3}, 10 \mathrm{mM} \mathrm{CaCl}_{2}$ ). $20 \mathrm{ml}$ of lipocyte media were applied to the column and unbound inhibitors eluted by gravity with $20 \mathrm{ml}$ of chromatography buffer (eluate A), followed by an equal volume of chromatography buffer containing $1 \mathrm{M}$ $\mathrm{NaCl}$ (eluate B). Bound gelatinases were eluted from the column with $20 \mathrm{ml}$ of chromatography buffer containing $1 \mathrm{M} \mathrm{NaCl}$ and 5\% DMSO (eluate C). Eluates A and B were concentrated 10-fold over a YM10 25-ml ultrafiltration membrane (Amicon Corp., Scientific Sys. Division, Danvers, MA). After dialysis into chromatography buffer, total gelatinase activity was determined in the original lipocyte medium and in eluates A, B, and C as previously described (12). Samples were assayed after activation by incubation with $1 \mathrm{mM}$ aminophenylmercuric acetate (Sigma Chemical Co.) at $37^{\circ} \mathrm{C}$ for $1 \mathrm{~h}$. Inhibitory activity in eluates $A$ and $B$ was assayed by adding $10 \times$ concentrates of these fractions to gelatinase activity in eluate $\mathrm{C}$.

$R N A$ extraction and Northern blotting. Total RNA was extracted and purified from freshly isolated lipocytes, and from the same preparation of cells after $4 \mathrm{~d}$ in primary culture, using the method of Chomcynzski and Saachi (24). Equal quantities of RNA from each experimental condition were subjected to Northern analysis using $(a)$ a fulllength $0.9-\mathrm{kb}$ cDNA probe to TIMP-1 (25) labeled with $\left[{ }^{32} \mathrm{P}\right] \mathrm{ATP}$ by random priming using the Klenow enzyme (Amersham Int., Aylesbury, UK); and (b) antisense RNA to $\beta$-actin, labeled with $\left[{ }^{32}\right.$ P]UTP by in vitro transcription of a pSP6- $\beta$-actin antisense control template (Ambion Inc., Austin, TX). After each hybridization, membranes were washed at $70^{\circ} \mathrm{C}$ in $0.1 \%$ standard saline citrate (SSC)/0.1\% SDS and exposed to Kodak X-omat S film for $24-48$ h at $-70^{\circ} \mathrm{C}$.

\section{Results}

Immunolocalization of TIMP-1 in cultured human hepatic lipocytes. TIMP-1 was immunolocalized in monensin-treated cultures of human lipocytes. The fluorescence was concentrated in the perinuclear cytoplasm (Fig. $1 b$ ), consistent with the distribution of the Golgi. Without monensin pretreatment, immunostaining for TIMP-1 was either negative or barely detectable in cultured human lipocytes (not shown). No fluorescence was demonstrable in nonimmune sheep IgG controls. The identity of TIMP-1-positive cells was confirmed by several means. The cells had the typical phase contrast morphology of lipocytes in primary culture (Fig. $1 a$ ) and displayed vitamin A autofluorescence (8). TIMP-1-positive cells stained positive for desmin (Fig. 2, $a$ and $b$ ) and negative for MAC-387 (a macrophage cell marker) by dual immunofluorescence (Fig. 2, $c$ and $d)$.

Quantitation of immunoreactive TIMP-1 release by cultured lipocytes. Human lipocytes cultured in serum-free media released $173 \pm 74 \mathrm{ng}$ (mean \pm SD) of free TIMP-1/106 cells per $24 \mathrm{~h}(n=5)$ as determined by ELISA. TIMP-1 was not detected in cell-free blank medium. For human lipocytes cultured in the presence of cycloheximide $10 \mu \mathrm{g} / \mathrm{ml}$, TIMP-1 release was inhib-
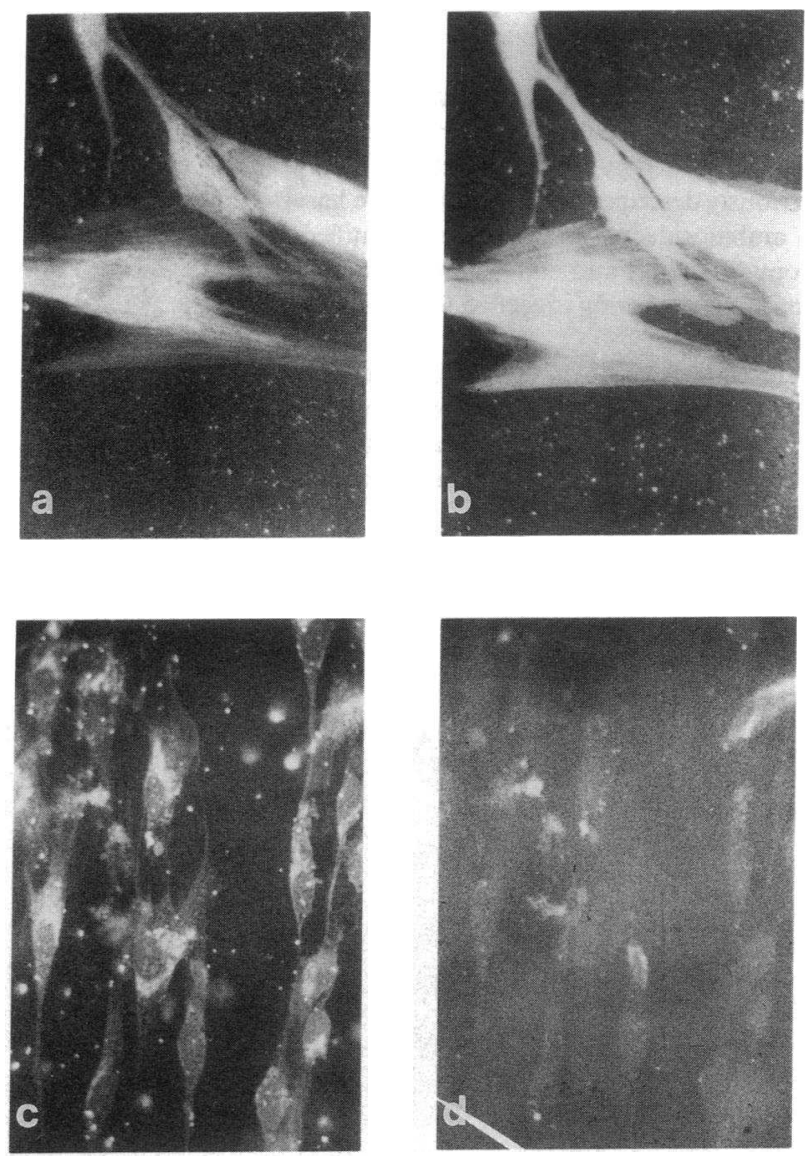

Figure 2. Co-localization of TIMP-1 to desmin-positive, MAC-387-negative cells. Lipocytes at day 14 in primary culture were immunostained for TIMP-1 ( $a$ and $c$ ) using FITC conjugate as described in Methods. Dual immunostaining was performed for either desmin $(b)$ or MAC-387 (d) as described in Methods, using RITC conjugate. TIMP-1-positive cells stained positively for desmin ( $a$ and $b$, respectively), but were MAC-387 negative ( $c$ and $d$, respectively).

ited more than $90 \%$ compared to control, implying that TIMP1 was either synthesized de novo or that cellular protein synthesis is necessary for its subsequent extracellular release.

Detection of TIMP-1 activity by reverse zymography. Media from cultured human hepatic lipocytes demonstrated a distinct band of metalloproteinase inhibitor activity by reverse zymography. This inhibitor band migrated at $28 \mathrm{kD}$ and comigrated with a positive control sample of TIMP-1 (derived from human fetal lung fibroblasts; Fig. 3). In contrast, the TIMP-2-positive control sample migrated as a distinct band at $22 \mathrm{kD}$. Thus, the inhibitor activity secreted by cultured human hepatic lipocytes is of identical molecular size to TIMP-1. In the experiments reported here, we have found no evidence of TIMP-2 secretion, or of secretion of other smaller or larger proteinase inhibitors. No inhibitory activity was demonstrated in cell-free blank media.

Quantitative analysis of metalloproteinase inhibitory activity in human lipocyte medium. Before separation of inhibitors by gelatin-sepharose chromatography, there was a low but detectable gelatinase activity $(2.44 \mu \mathrm{g}$ gelatin degraded $/ 18 \mathrm{~h})$ in lipocyte medium. Chromatography of this medium markedly 

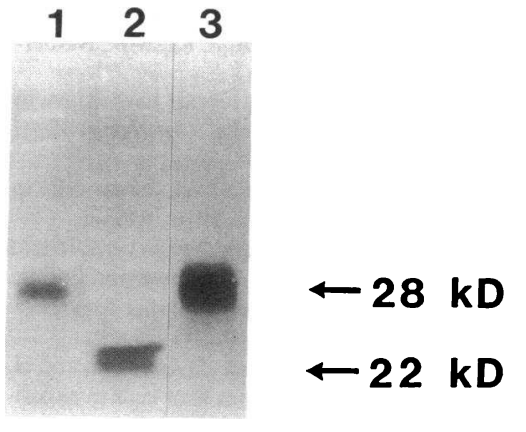

Figure 3. Reverse zymography of human lipocyte media. Serumfree media were harvested after $24 \mathrm{~h}$ collection from 14-d-old primary cultures of human lipocytes, and analyzed by reverse zymography as described in Methods. This figure demonstrates one representative example of five separate experiments. Media from human lipocytes (lane $l$ ) is compared with a positive control for TIMP-2, (lane 2); and TIMP-1, (lane 3). A band of inhibitory activity is demonstrated at $28 \mathrm{kD}$ in the human lipocyte media that co-migrates with the TIMP-1, and not the TIMP-2-positive control.

increased detectable gelatinase activity more than 20 -fold compared to intact medium. Gelatinase activity in eluates A (chromatography buffer wash: $0.313 \mu$ g gelatin degraded $/ 18 \mathrm{~h}$ ) or B (chromatography buffer wash $+1 \mathrm{M} \mathrm{NaCl}: 0.939 \mu \mathrm{g}$ gelatin degraded $/ 18 \mathrm{~h}$ ), were minimal. In contrast, markedly increased gelatinase activity was detected in eluate $\mathrm{C}$ (chromatography buffer $+5 \%$ DMSO wash: $46.8 \mu$ g gelatin degraded/18 h).

The high gelatinase activity detected in eluate $C$ could be reinhibited by adding back dialyzed $10 \times$ concentrates of either eluate $\mathrm{A}$ (chromatography buffer wash) or eluate $\mathrm{B}$ (chromatography buffer wash $+1 \mathrm{M} \mathrm{NaCl}$ ). Inhibition of gelatinase activity by eluates A and B were $69 \%$ and $56 \%$, respectively, compared with control (see Table I).

Expression of TIMP-1 mRNA by cultured human hepatic lipocytes. Total cellular RNA prepared from cultured human hepatic lipocytes and examined by Northern analysis with high stringency washing revealed a single hybridization signal of 0.9 $\mathrm{kb}$ (Fig. 4). This transcript size corresponds with that reported for TIMP-1 mRNA in other human fibroblast cell lines (23, 26). Moreover, increasing duration of primary lipocyte culture was associated with a specific increase in TIMP-1 mRNA ex-

Table I. Inhibitory Activity of Eluates Obtained from GelatinSepharose Affinity Chromatography of Human Lipocyte Medium

\begin{tabular}{ccc}
\hline & Gelatinase activity & $\begin{array}{c}\text { Inhibition } \\
\text { of control }\end{array}$ \\
\hline $\begin{array}{c}\text { Eluate C containing 10\% (vol/vol) } \\
\text { chromatography buffer (control) }\end{array}$ & $\begin{array}{c}20.2 \mu \text { g gelatin } \\
\text { degraded/18 h }\end{array}$ & $0 \%$ \\
$\begin{array}{c}\text { Eluate C containing 10\% vol/vol) } \\
\text { of 10x eluate A }\end{array}$ & $\begin{array}{c}6.24 \mu \mathrm{g} \text { gelatin } \\
\text { degraded/18 h }\end{array}$ & $69.2 \%$ \\
$\begin{array}{c}\text { Eluate C containing 10\% (vol/vol) } \\
\text { of 10x eluate B }\end{array}$ & $\begin{array}{c}8.78 \mu \mathrm{g} \text { gelatin } \\
\text { degraded/18 h }\end{array}$ & $56.5 \%$ \\
\hline
\end{tabular}

Eluates A and B from gelatin-sepharose chromatography of lipocyte medium (see Methods) were concentrated 10x using a YM10 25ml ultrafiltration membrane (Amicon Corp.). The concentrates were then dialyzed against chromatography buffer before being added to eluate C (see Methods) as a 10\% (vol/vol) solution. Gelatinase activities were determined as described in the text. Results are expressed as percentage of inhibitory activity compared with the control sample (chromatography buffer alone). a. b. c. d.

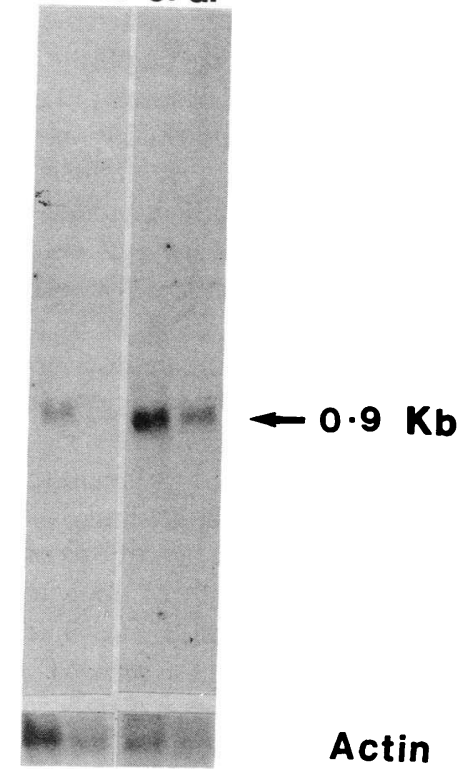

Figure 4. Northern blot analysis of total RNA prepared from freshly isolated and cultured human hepatic lipocytes. Total RNA was prepared from human lipocytes and analyzed by Northern blotting using a fulllength CDNA probe for human TIMP-1. After autoradiography, the TIMP-1 probe was removed by washing membranes in TE. with $0.1 \%$ SDS at $80^{\circ} \mathrm{C}$. Membranes were then rehybridized with an antisense RNA probe for $\beta$ actin (see Methods). (Lanes $a$ and $b$ ) 10 and 5 $\mu \mathrm{g}$, respectively, of RNA prepared from freshly isolated cells. (Lanes $c$ and $d$ ) 10 and 5 $\mu \mathrm{g}$, respectively, of RNA from the same cell preparation after $4 \mathrm{~d}$ in primary culture.

pression relative to $\beta$-actin mRNA. In total RNA prepared from freshly isolated lipocytes, a signal was barely detectable, whereas expression of TIMP-1 mRNA was markedly increased after $4 \mathrm{~d}$ in primary culture (Fig. 4).

\section{Discussion}

TIMP-1 is a $28-\mathrm{kD}$ glycoprotein that is secreted by a wide variety of fibroblasts and other cell types $(27,28)$, but synthesis and release of TIMP-1 by cells of hepatic origin has not previously been described. Our data demonstrate that primary cultures of hepatic lipocytes (fat-storing or Ito cells) purified from human liver express mRNA for TIMP-1 and synthesize immunoreactive TIMP-1, as determined by immunolocalization of TIMP-1 to the Golgi of monensin-treated cells. Moreover, we have demonstrated by ELISA that cultured human lipocytes secrete immunoreactive TIMP-1, and have used reverse zymography to demonstrate metalloproteinase inhibitory activity, of appropriate molecular size for TIMP-1 $\left(M_{\mathrm{r}} 28 \mathrm{kD}\right)$. We therefore conclude that cultured human lipocytes express the gene for, synthesize, and secrete biologically active TIMP-1.

The marked increase in gelatinase activity after removal of inhibitor by gelatin sepharose chromatography suggests that TIMP-1 is an important regulatory mechanism for matrix degradation in liver. Since by reverse zymography the same media contained no other metalloproteinase inhibitors, the observed gelatinase inhibitory activity can be ascribed to TIMP-1. The 20 -fold increase in gelatinase activity after separation from inhibitors by chromatography suggests that TIMP-1 is a major factor regulating matrix metalloproteinase activity of hepatic lipocytes.

Our results indicate that the relative expression of TIMP-1 is determined in part by the state of activation of lipocytes, because TIMP-1 expression increased with duration of primary culture (Fig. 4). Accumulated evidence has demonstrated that lipocytes grown on uncoated plastic adopt an activated phenotype with increasing duration of cultures that closely parallels 
their transition to myofibroblast-like cells in vivo during liver injury. Features of this activation have been well characterized for both rat and human lipocytes in primary culture on plastic, and include cell spreading $(8,29)$, loss of retinoid droplets $(30)$, induction of cytokine receptors $(31)$, proliferation $(8,29)$, expression of smooth muscle-specific actin (32), increased matrix production $(33,34)$, and gene expression $(8)$. Although accelerated by Kupffer cell-derived factor(s) (31), activation of cultured lipocytes is not dependent on this mechanism. Recent studies have emphasized that lipocyte activation occurs as a feature of duration of culture and have suggested that autocrine secretion of transforming growth factor- $\beta 1$ may be important in this process (33). Whatever the mechanism, increased matrix production by activated lipocytes is particularly relevant to our current study of matrix metalloproteinase regulation.

Taken together, these data suggest a working hypothesis of how matrix deposition may be altered as a result of lipocyte activation. Transformation of lipocytes to myofibroblast-like cells is associated with a marked increase in matrix secretion ( 7 , $9,11,33,34)$, which is accompanied by increases not only in matrix metalloproteinase secretion $(12,13)$ but also TIMP-1 release. The net effect of these alterations may be reduced matrix degradation resulting in marked increases in matrix deposition in liver. This view does not account for the potential contributions of other regulatory mechanisms or of other sinusoidal cells to matrix homeostasis. Nonetheless, the findings clearly indicate that lipocytes can regulate matrix turnover at many levels and, therefore, provide additional support for a critical role for these cells in liver injury and repair.

Previous experimental evidence supports a role for metalloproteinases and their inhibitors in pathological liver fibrosis. In animal models of liver injury, as fibrosis progresses, total collagenase activity decreases relative to liver collagen content (35, 36). Moreover, experimental models such as carbon tetrachloride suggest that early on, fibrosis is reversible, but that after repeated exposure liver fibrosis progresses to cirrhosis, even if the original hepatotoxin is withdrawn (37). The explanation for these phenomena is unknown, but our observation that lipocytes with a myofibroblast-like phenotype synthesize and release TIMP-1 suggests one potential mechanism. We hypothesize that release of TIMP-1 by activated hepatic lipocytes may, by inhibition of metalloproteinases (particularly interstitial collagenase), contribute to the progression of liver fibrosis.

\section{Acknowledgments}

We thank Glenn Yamasaki for technical assistance with lipocyte preparation, Linda Wong for RNA harvesting/electrophoresis, and Mary Harrison for ELISA assays.

This work was supported by the Wellcome Trust (project grant 030349), the Wessex Medical Trust, and in part by United States Public Health Service grants DK37340 and DK-39506 from the National Institutes of Health. Dr. S. Friedman is a recipient of an American Heart association grant-in-aid award. Dr. J. Iredale is a Medical Research Council Training Fellow. Dr. G. Murphy is supported by the Arthritis and Rheumatism Council. Dr. R. Hembry is supported by the Medical Research Council.

\section{References}

1. De Leeuw, A. M., C. F. A. Van Bezooijen, and D. L. Knook. 1986. Changes in the ratio between sinusoidal and parenchymal cell numbers of the rat liver during development and aging. In Cells of the Hepatic Sinusoid. Vol. 1. A. Kim, E. Wisse, and D. L. Knook, editors. Kupffer Cell Foundation, Rijswijk, Netherlands. pp. 463-468.

2. Mak, K. M., A. M. Leo, and C. S. Lieber. 1984. Alcoholic liver injury in baboons: transformation of lipocytes to transitional cells. Gastroenterology. 87:188-200.

3. Mak, K. M., and C. S. Lieber. 1988. Lipocytes and transitional cells in alcoholic liver disease: a morphometric study. Hepatology. 8:1027-1033.

4. Milani, S., H. Herbst, D. Schuppan, E. G. Hahn, and H. Stein. 1989. In situ hybridization for procollagen types I, III, and IV mRNA in normal and fibrotic rat liver: evidence for predominant expression in nonparenchymal liver cells. Hepatology. 10:84-92.

5. Milani, S., H. Herbst, D. Schuppan, K. Young-Kim, E. D. Riecken, and H. Stein. 1990. Procollagen expression by nonparenchymal rat liver cells in experimental biliary fibrosis. Gastroenterology. 98:175-184.

6. Milani, S., H. Herbst, D. Schuppan, C. Surrenti, E. D. Riecken, and H. Stein. 1990. Cellular localization of type I, III, and IV procollagen gene transcripts in normal and fibrotic human liver. Am. J. Pathol. 137:59-70.

7. Friedman, S. L., F. J. Roll, J. Boyles, and D. M. Bissell. 1985. Hepatic lipocytes: the principal collagen-producing cells of normal rat liver. Proc. Natl. Acad. Sci. USA. 82:8681-8685.

8. Friedman, S. L., D. C. Rockey, R. F. McGuire, J. J. Maher, J. K. Boyles, and G. Yamasaki. 1992. Isolated hepatic lipocytes and Kupffer cells from normal human liver-morphologic and functional characteristics in primary culture. Hepatology. 15:234-243.

9. Maher, J. J., S. L. Friedman, F. J. Roll, and D. M. Bissell. 1988. Immunolocalization of laminin in the normal rat liver and biosynthesis of laminin by hepatic lipocytes in primary culture. Gastroenterology. 94:1053-1062.

10. Ramadori, G., H. Rieder, T. H. Knittel, H. P. Dienes, and K. Meyer zum Buschenfelde. 1987. Fat storing cells (FSC) of rat liver synthesize and secrete fibronectin. Comparison with hepatocytes. J. Hepatol. 4:190-197.

11. Gressner, A. M. 1991. Time-related distribution profiles of sulfated glycosaminoglycans in cells, cell surfaces, and media of cultured rat liver fat-storing cells. Soc. Exp. Biol. Med. 196:307-315.

12. Arthur, M. J. P., S. L. Friedman, F. J. Roll, and D. M. Bissell. 1989. Lipocytes from normal rat liver release a neutral metalloproteinase that degrades basement membrane (type IV) collagen. J. Clin. Invest. 84:1076-1085.

13. Arthur, M. J. P., C. L. Jackson, and S. L. Friedman. 1991. Release of type IV collagenase/gelatinase by human lipocytes. In Cells of the Hepatic Sinusoid. E. Wisse, D. L. Knook, and K. Decker, editors. Kupffer Cell Foundation, Rijswijk, Netherlands. 161-163.

14. Emonard, H., A. Guillouze, Ch.M. Lapiere, and J. A. Grimaud. 1990. Human liver fibroblast capacity for synthesizing interstitial collagenase in vitro. Cell. Mol. Biol. 36:461-467.

15. Herbst, H., O. Heinrichs, D. Schuppan, S. Milani, and H. Stein. 1991 Temporal and spatial patterns of transin/stromelysin RNA expression following toxic injury in rat liver. Virchows Arch. B Cell Pathol. 60(5):295-300.

16. Bhatnagar, R., U. Schade, E. T. Rietschel, and K. Decker. 1982. Involvement of prostaglandin $\mathrm{E}$ and adenosine $3^{\prime} 5^{\prime}$-monophosphate in lipopolysaccharide-stimulated collagenase release by rat Kupffer cells. Eur. J. Biochem. 124:2405-2409.

17. Winwood, P. J., P. S. Kowalski-Saunders, and M. J. P. Arthur. 1991. Kupffer cells release a $95 \mathrm{kD}$ metalloproteinase with degradative activity against gelatin. Gut. 32:A837-A838.

18. Murphy, G., R. M. Hembry, C. E. Hughes, A. J. Fosgang, and T. E. Hardingham. 1990. Role and regulation of metalloproteinases in connective tissue turnover. Biochem. Soc. Trans. 18:812-815.

19. Hembry, R. M., G. Murphy, and J. J. Reynolds. 1985. Immunolocalization of tissue inhibitor of metalloproteinases (TIMP) in human cells. Characterization and use of a specific serum. J. Cell Sci. 73:105-119.

20. Flavell, D. J., D. B. Jones, and D. H. Wright. 1987. Identification of tissue histiocytes on paraffin sections by a new monoclonal antibody. J. Histochem. Cytochem. 35:1217-1226.

21. Cooksley, S., J. B. Hipkiss, S. P. Tickle, E. Holmes-levers, A. J. P. Docherty, G. Murphy, and A. D. G. Lawson. 1990. Immunoassays for the detection of human collagenase, stromelysin, tissue inhibitor of metalloproteinase (TIMP), and enzyme-inhibitor complexes. Matrix. 10:285-291.

22. Ward, R. V., R. M. Hembry, J. J. Reynolds, and G. Murphy. 1991. The purification of tissue inhibitor of metalloproteinases- 2 from its $72-k D$ progelatinase complex. Biochem. J. 278:179-187.

23. Overall, C. M., J. L. Wrana, and J. Sudek. 1989. Independent regulation of collagenase, $72 \mathrm{kD}$ progelatinase, and metalloendoproteinase inhibitor expression in human fibroblasts by transforming growth factor- $\beta$. J. Biol. Chem. 264:1860-1869.

24. Chomcynzski, P., and N. Saachi. 1987. Single step method of RNA isolation by acid guanidinium thiocyanate-phenol-chloroform extraction. Anal. Biochem. 162:156-159.

25. Docherty, A. J. P., A. Lyons, B. J. Smith, E. M. Wright, P. E. Stephens, 
and T. J. R. Harris. 1985. Sequence of human tissue inhibitor of metalloproteinases and its identity to erythroid-potentiating activity. Nature (Lond.). 318:66-69.

26. Edwards, D. R., G. Murphy, J. J. Reynolds, S. E. Whitham, A. J., Docherty, P. Angel, and J. K. Heath. 1987. Transforming growth factor beta modulates expression of collagenase and metalloproteinase inhibitor. EMBO (Eur Mol. Biol. Organ.) J. 6:1899-1904.

27. Murphy, G., E. C. Cartwright, A. Sellers, and J. J. Reynolds. 1977. The detection and characterization of collagenase inhibitors from rabbit tissue in culture. Biochem. Biophys. Acta. 483:493-498.

28. Welgus, H. G., G. P. Stricklin, A. Z. Eisen, E. A. Baker, R. V. Cooney, and J. J. Jeffrey. 1979. A specific inhibitor of vertebrate collagenase produced by human skin fibroblasts. J. Biol. Chem. 254:1938-1943.

29. Friedman, S. L., F. J. Roll, J. Boyles, D. M. Arenson, and D. M. Bissell. 1989. Maintenance of differentiated phenotype of cultured rat hepatic lipocytes by basement membrane matrix. J. Biol. Chem. 264:10756-10762.

30. Friedman, S. L., and W.S. Blaner. 1989. Activation of hepatic lipocytes by Kupffer cell medium is accompanied by release of retinol. Gastroenterology. 96:A598.
31. Friedman, S. L., and M. J. P. Arthur. 1989. Activation of cultured rat hepatic lipocytes by Kupffer cell conditioned medium. J. Clin. Invest. 84:17801785 .

32. Rockey, D. C., J. K. Boyles, G. Gabbiani, and S. L. Friedman. 1992. Rat hepatic lipocytes acquire a smooth muscle phenotype during cellular activation in culture and in vivo. J. Submicrosc. Cytol. Pathol. 24:193-203.

33. Bachem, M. G., D. Meyer, R. Melchior, K.-M. Sell, and A. M. Gressner. 1992. Activation of rat liver perisinusoidal lipocytes by transforming growth factors derived from myofibroblast-like cells. J. Clin. Invest. 89:19-27.

34. Geerts, A., R. Vrijsen, J. Rauterberg, A. Burt, P. Schellinck, and E. Wisse. 1989. In vitro differentiation of fat-storing cells parallels marked increase of collagen synthesis and secretion. J. Hepatol. 9:59-68.

35. Perez-Tamayo, R., I. Montfort, and E. Gonzalez. 1987. Collagenolytic activity in experimental cirrhosis of the liver. Exp. Mol. Pathol. 47:300-308.

36. Montfort, I., R. Perez-Tamayo, A. M. Alvizouri, and E. Tello. 1990. Collagenase of hepatocytes and sinusoidal liver cells in the reversibility of experimental cirrhosis of the liver. Virchows Arch. B Cell Pathol. 59:281-289.

37. Montfort, I., and R. Perez-Tamayo. 1978. Collagenase in experimental carbon tetrachloride cirrhosis of the liver. Am. J. Pathol. 92:411-420. 